\title{
THE ACTION OF $p$-AMINOSALICYLIC ACID ON PROTHROMBIN TIME IN MAN
}

\author{
BY \\ A. L. TÁRNOKY AND L. STEINGOLD \\ From the Group Laboratory, Mile End Hospital, London, and the Pathological \\ Laboratory, St. Andrew's Hospital, Bromley-by-Bow, London
}

(RECEIVED FOR PUBLICATION APRIL 11, 1951)

\begin{abstract}
A lengthening in prothrombin time by giving salicylates was first observed in the animal experiments of Link, Overman, Sullivan, Huebner, and Scheel (1943). This result, and a comparison of the structures of coumarin-like anticoagulants (Overman, Stahmann, Huebner, Sullivan, Spero, Doherty, Ikawa, Graf, Roseman, and Link, 1944), led Link to conclude that dicoumarol (3,3'-methylenebis [4hydroxycoumarin]) acts on breaking down in vivo to the chemically related salicylic acid. The experimental findings of Link and his colleagues have been amply confirmed and extended to man (Meyer and Howard, 1943 ; Shapiro, Redish, and Campbell, 1943 ; Clausen and Jager, 1946 ; Dibenedetto Dell' Aquila and Lojacono, 1946 ; Owen and Bradford, 1946 ; Zimmerman and Shapiro, 1946 ; Nitshe, Gerarde, and Deutsch, 1947). Their hypothesis, however, has not found complete acceptance, although the only direct evidence against it is the absence of salicylates in the urine after treatment with dicoumarol (Lester, 1944).

Jaques and Lepp (1947) found that rabbits given salicylate by mouth, or dicoumarol either by mouth or intravenously, showed a lengthening of prothrombin time. Intravenous salicylate had no effect, neither did salicylate given orally together with surcinylsulphathiazole. They advanced the view that salicylate may be converted to a dicoumarol-like substance by bacterial synthesis in the intestine.

It was hoped that a comparison of blood salicylate levels and prothrombin times in patients receiving salicylate and in those receiving dicoumarol would yield further information on their mode of action. During this investigation, which was making slow progress owing to the lack of suitable patients, the analogous case of $p$-aminosalicylic acid (P.A.S.), used in the treatment of tuberculosis, was given consideration.<smiles>CC1(C)C(=O)Oc2cc(N)ccc2C1(C)Oc1cc(N)ccc1O</smiles>

The structural relationship of P.A.S. to the dicoumarol analogue 3,3'-methylenebis [7-amino-4-hydroxycoumarin] is that of salicylic acid to dicoumarol itself, and their biological relationship may be expected to be similar. Thus on Link's hypothesis the dicoumarol analogue should break down to P.A.S. in vivo and give a more constant blood level of the drug than does the administration of P.A.S. itself. On the Jaques and Lepp theory the diaminodicoumarol or a related compound
\end{abstract}


may be synthesized in vivo from P.A.S., and its possible anticoagulant properties will assume importance. Attempts to synthesize diaminodicoumarol and related substances were made at our request by workers in the Research Department of Herts Pharmaceuticals Ltd. (Drain and Seymour).

The possible salicylate-like, antiprothrombin effect of P.A.S. has been noted by several observers. It was first mentioned as a possibility by O'Connor (1948), and some decrease in prothrombin levels was found by Bavin (1949) in animal experiments. Similar observations have since been reported by Nagley (1949), Swanson (1949), and Fisher (1949) in man. The blood prothrombin contents in these cases did not fall to danger level, but Fisher suggested that combined treatment with P.A.S. and streptomycin would increase the tendency towards hypoprothrombinaemia, since the bacteriostatic effect of streptomycin on Esch. coli might deplete the host of vitamin K. Barclay (1949) has reported an antiprothrombin effect of intravenous P.A.S. in man; this resembles the findings of Link et al. (1943) and would seem to differ from those of Jaques and Lepp (1947). The most recent work on the subject is that reported from Farnborough Hospital by Madigan, Griffiths, Lynch, Bruce, Kay, and Brownlee (1950) and Lynch (1950). They have examined the question with the clinical aspect in mind, and think that the changes are probably not significant. Lynch assumes the analogy of P.A.S. to salicylate and discusses Link's hypothesis, which he finds is not confirmed. The same assumption is made here, and the theories of Link et al. and of Jaques and Lepp are assumed to refer equally to salicylic acid and to P.A.S.

\section{Experimental}

The investigation was conducted during the routine therapy of tuberculous patients and was subordinated to their course of treatment.

Clinical Material.-Three groups of patients were investigated.

Cases on P.A.S. Alone.-These were Cases 1-6.

Cases on P.A.S. and Streptomycin.-This group comprise Cases 7-9. Streptomycin was given with P.A.S. after the antiprothrombin effect of the latter alone had been observed. The effect of streptomycin alone was investigated in two control cases, patients suffering from tuberculosis.

Cases on P.A.S. and Succinylsulphathiazole.-These were Cases 12-14. P.A.S. therapy was supplemented in this group after a few weeks by a short course of succinylsulphathiazole. The effect of succinylsulphathiazole alone was investigated in three healthy volunteers (Cases 15-17, Table I). Case 17 was in addition given vitamin-K analogue "synkavit" (Roche).

Dosage.-Two schemes of P.A.S. dosage were used : 140 g. Na-P.A.S. per week (Cases 1, 5, 7, and 8), and 120 g. Na-P.A.S. per week (Cases 2, 3, 4, 6, 9, 10, 12, 13, and 14). The drug was given on six days, and not on the seventh of each week.

The dosage of streptomycin was $0.5 \mathrm{~g}$. b.d. intramuscularly.

The "synkavit" given orally to Case 17 consisted of $10 \mathrm{mg}$. t.d.s. for two days before his control curve began to be charted ; it was then increased to $40 \mathrm{mg}$. t.d.s., and succinylsulphathiazole administration was started.

Methods.-Venous blood was collected before the beginning of P.A.S. therapy and thereafter usually at weekly intervals. Specimens were taken exactly 15 minutes (in Cases $1,2,3,5,7,8$, and 10 ) or exactly 30 minutes (in Cases $4,6,9,12,13$, and 14) after the second (mid-morning) daily dose of P.A.S. 


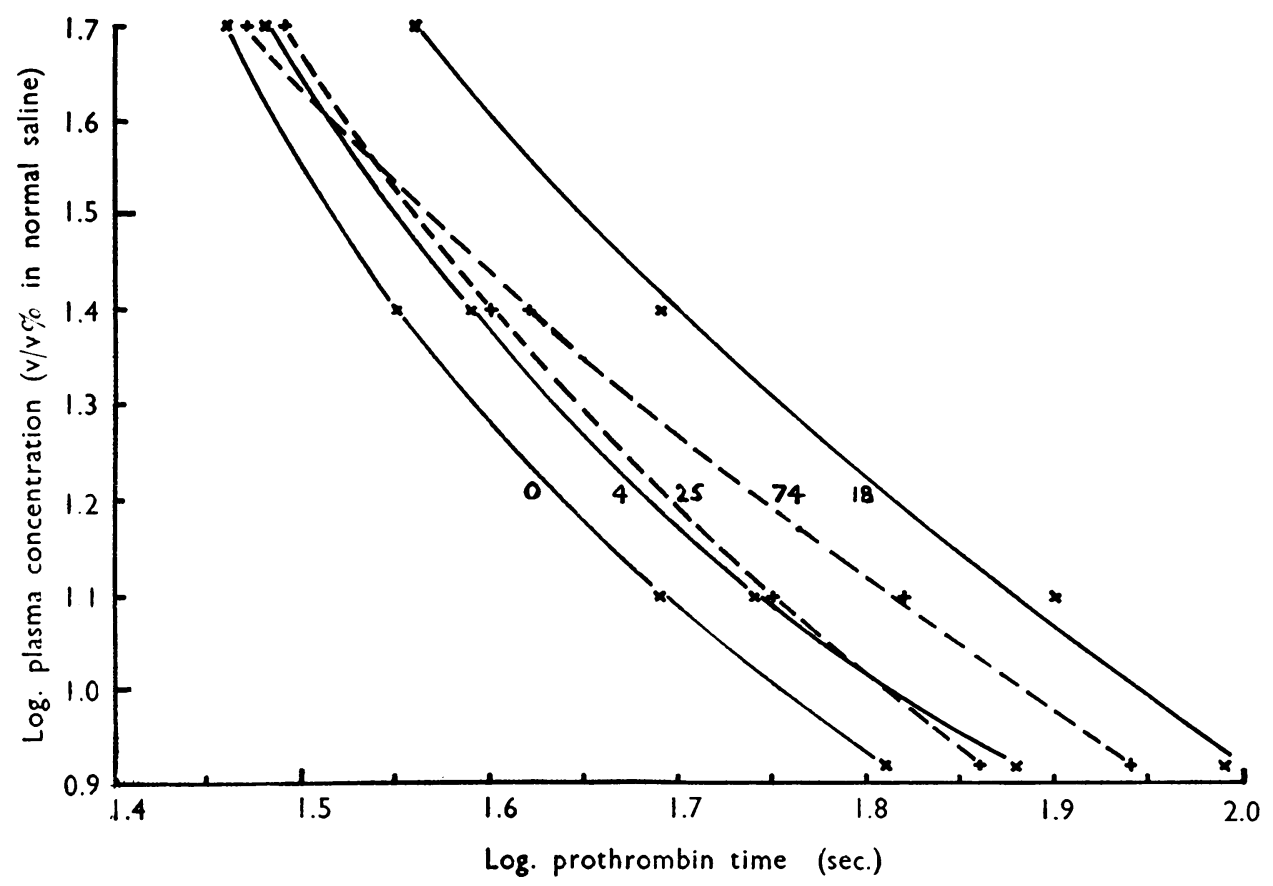

FIG. 1.-Anticoagulant effect of P.A.S. and its inhibition by streptomycin in Case 7 (A.L.). The figures against the curves give the number of days on P.A.S. before the prothrombin determination was made. On P.A.S. therapy $\times-\longrightarrow \times$; on combined P.A.S. and streptomycin therapy +---+ .

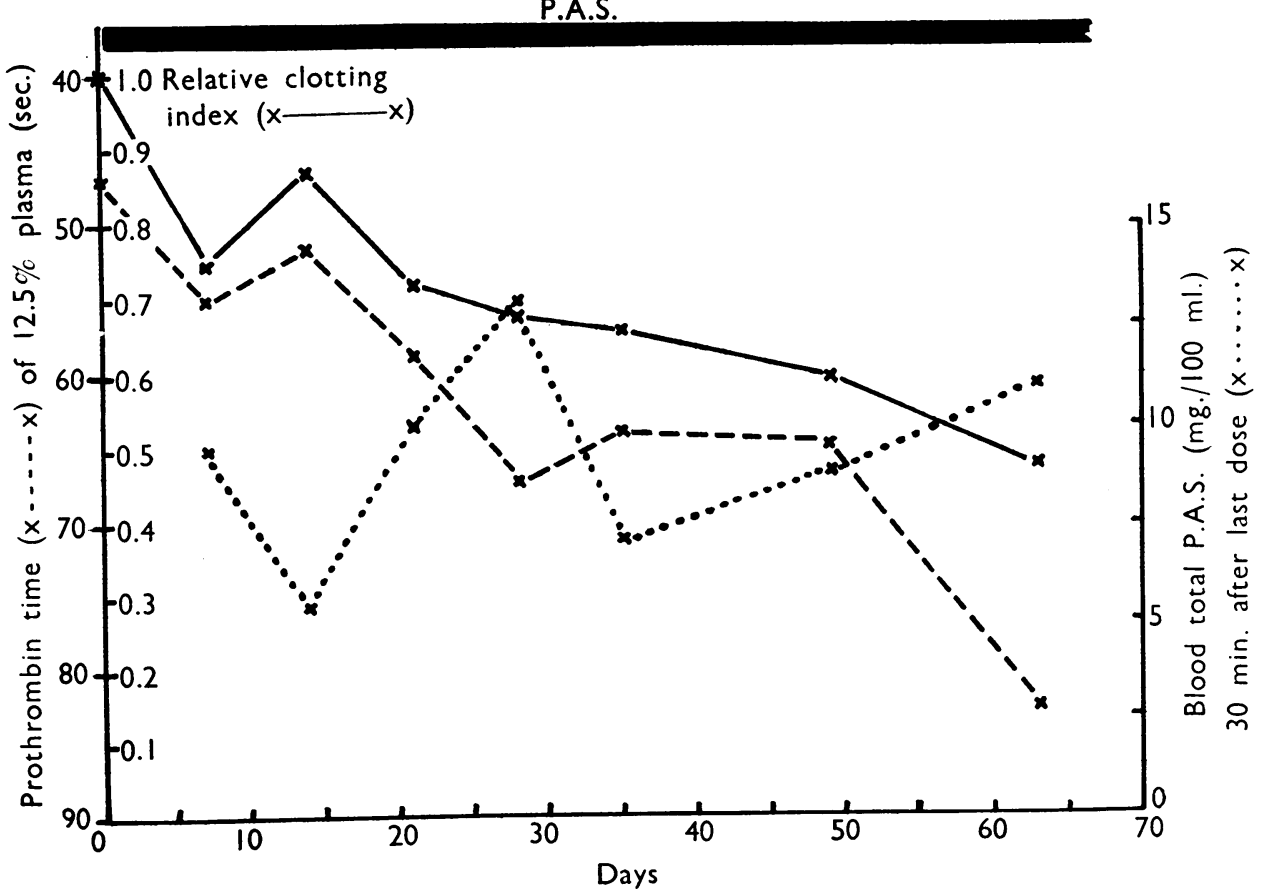

FIG. 2.-Case 4 (J.R.) treated with P.A.S. 
P.A.S.

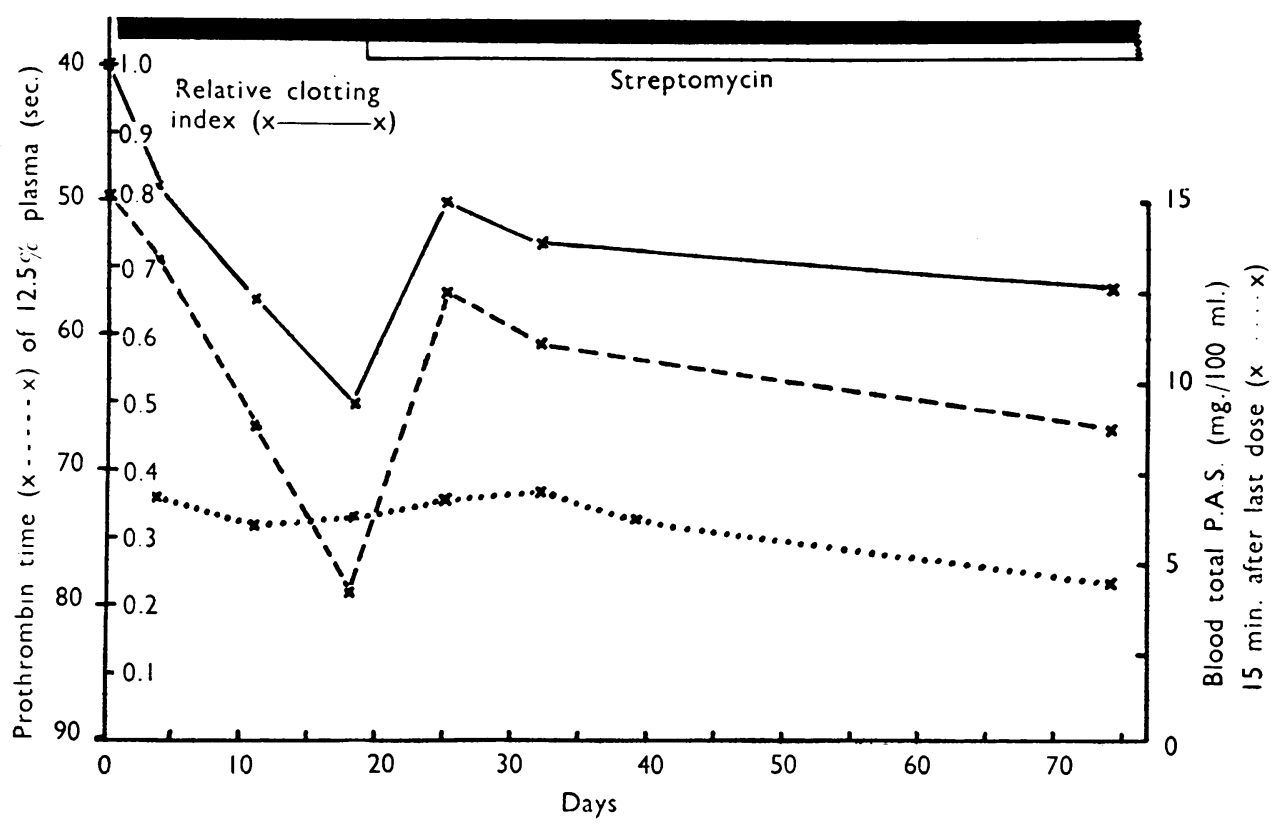

FIG. 3.-Case 7 (A.L.) treated with P.A.S. and streptomycin.

P.A.S.

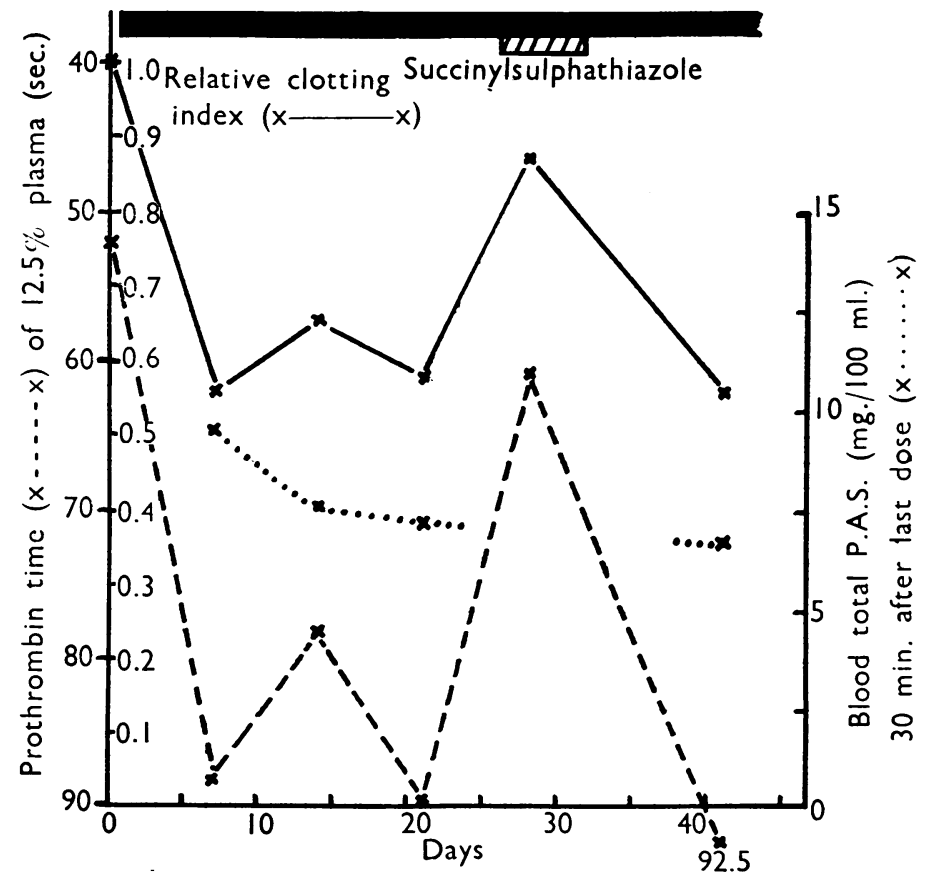

Fig. 4.-Case 12 (R.H.) treated with P.A.S. and succinylsulphathiazole. 
TABLE I

Analysis of Results in Patients and Controls

\begin{tabular}{|c|c|c|c|c|c|}
\hline $\begin{array}{l}\text { Case } \\
\text { No. }\end{array}$ & Name & $\begin{array}{c}\text { Day of } \\
\text { Observation }\end{array}$ & $\begin{array}{l}\text { Prothrombin } \\
\text { Time of } 12 \cdot 5 \% \\
\text { Plasma (sec.) }\end{array}$ & $\begin{array}{l}\text { Relative } \\
\text { Clotting } \\
\text { Index }\end{array}$ & $\begin{array}{l}\text { Blood Total } \\
\text { P.A.S. } \\
\text { (mg./100 ml.) }\end{array}$ \\
\hline 1 & E.G. & $\begin{array}{r}0 \\
6 \\
6 \\
13 \\
20 \\
27 \\
34 \\
41 \\
48 \\
76\end{array}$ & \begin{tabular}{|c|}
$42 \cdot 5$ \\
A.S. begun \\
$53 \cdot 5$ \\
$52 \cdot 5$ \\
$59 \cdot 5$ \\
57 \\
$56 \cdot 5$ \\
54 \\
55 \\
58
\end{tabular} & $\begin{array}{l}1 \\
0.66 \\
0.72 \\
0.62 \\
0.62 \\
0 \cdot 60 \\
0.65 \\
0.67 \\
0.63\end{array}$ & $\begin{array}{l}- \\
7 \cdot 3 \\
4 \cdot 4 \\
6 \cdot 5 \\
9 \cdot 2 \\
6 \cdot 2 \\
3 \cdot 7 \\
5 \cdot 9 \\
6 \cdot 5\end{array}$ \\
\hline 2 & M.S. & $\begin{array}{r}0 \\
7 \\
14 \\
21 \\
28 \\
35 \\
49\end{array}$ & \begin{tabular}{|c|}
41 \\
A.S. begun \\
54 \\
51 \\
53 \\
54 \\
48 \\
46.5
\end{tabular} & $\begin{array}{l}1 \\
0 \cdot 69 \\
0 \cdot 78 \\
0 \cdot 69 \\
0 \cdot 68 \\
0 \cdot 81 \\
0 \cdot 81\end{array}$ & $\begin{array}{r}- \\
7 \cdot 4 \\
7 \cdot 2 \\
8 \cdot 3 \\
7 \cdot 1 \\
11 \cdot 0 \\
6 \cdot 1\end{array}$ \\
\hline 3 & H.I. & $\begin{array}{r}0 \\
7 \\
14 \\
21 \\
28 \\
35 \\
42 \\
56 \\
70 \\
84\end{array}$ & \begin{tabular}{|c|}
66 \\
P.A.S. begun \\
50 \\
$49 \cdot 5$ \\
$54 \cdot 5$ \\
44 \\
51 \\
$49 \cdot 5$ \\
80 \\
$67 \cdot 5$ \\
63
\end{tabular} & $\begin{array}{l}1 \\
1.52 \\
1.26 \\
1.29 \\
1.51 \\
1.51 \\
1.56 \\
0.79 \\
0.85 \\
1.00\end{array}$ & $\begin{array}{l}- \\
7 \cdot 1 \\
4 \cdot 1 \\
6 \cdot 4 \\
6 \cdot 1 \\
4 \cdot 4 \\
3 \cdot 5 \\
7 \cdot 5 \\
8 \cdot 1 \\
6 \cdot 2\end{array}$ \\
\hline 5 & A.G. & $\begin{array}{c}0 \\
7 \\
\text { Drug not toler }\end{array}$ & $\begin{array}{c}43 \cdot 5 \\
\text { P.S. begun } \\
59 \cdot 5 \\
\text { ted } ; \text { treatment dis }\end{array}$ & $\begin{array}{c}1 \\
0.65 \\
\text { nued }\end{array}$ & - \\
\hline 6 & B.Z. & $\begin{array}{l}0 \\
7\end{array}$ & $\begin{array}{c}47 \cdot 5 \\
\text { P.A.S. begun }\end{array}$ & $\begin{array}{l}1 \\
1 \cdot 32\end{array}$ & $\begin{array}{l}- \\
9 \cdot 8\end{array}$ \\
\hline
\end{tabular}

Rapid deterioration; investigation not pursued, and drug withdrawn shortly afterwards

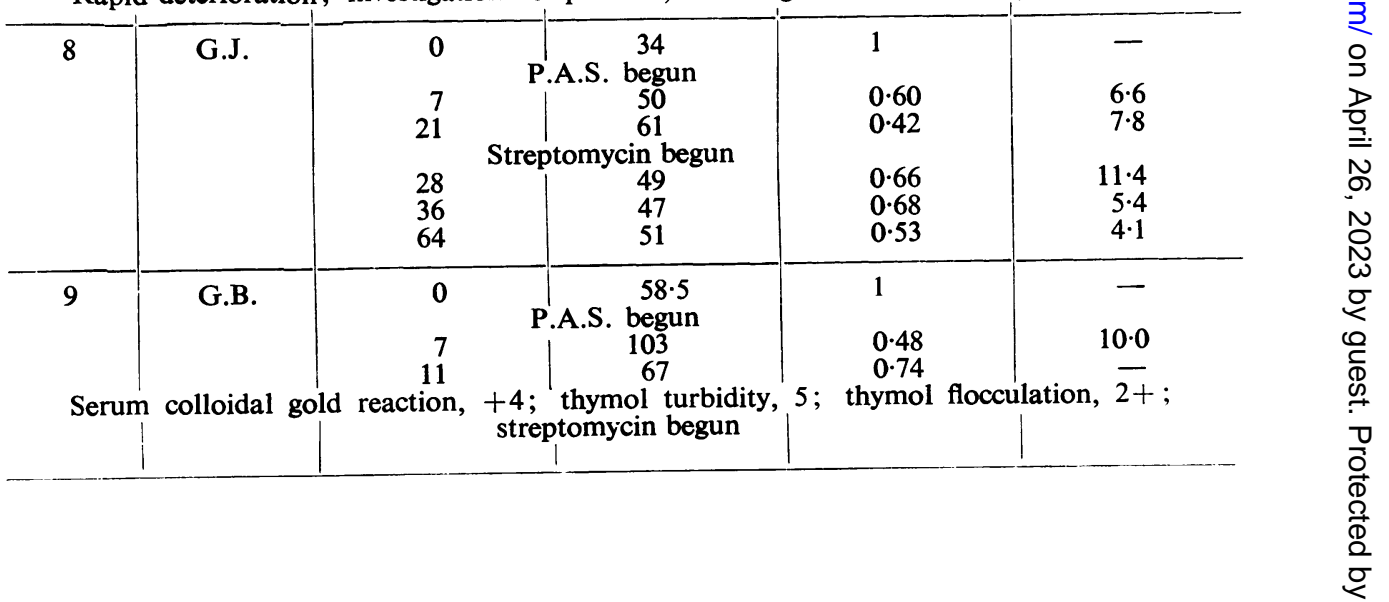


TABLE I-continued

\begin{tabular}{c|c|c|c|c|c}
\hline $\begin{array}{c}\text { Case } \\
\text { No. }\end{array}$ & Name & $\begin{array}{c}\text { Day of } \\
\text { Observation }\end{array}$ & $\begin{array}{c}\text { Prothrombin } \\
\text { Time of 12.5\% } \\
\text { Plasma (sec.) }\end{array}$ & $\begin{array}{c}\text { Relative } \\
\text { Clotting } \\
\text { Index }\end{array}$ & $\begin{array}{c}\text { Blood Total } \\
\text { P.A.S. } \\
\text { (mg./100 ml.) }\end{array}$ \\
\hline 9 contd. & G.B. & 14 & 74 & 0.69 & $7 \cdot 2$ \\
& & 21 & 94 & 0.59 & 6.9 \\
& & 38 & 67 & $0 \cdot 74$ & 13.2 \\
& & 42 & 69.5 & 0.74 & 6.6 \\
& 56 & 64 & 0.74 & 7.2 \\
& & 59 & 0.87 & 5.5
\end{tabular}

Serum colloidal gold reaction, +2 ; thymol turbidity, 4; thymol flocculation, $1+$ Bromsulphalein test ( $2 \mathrm{mg}$. dye/kg. body weight), $77 \cdot 5 \%$ eliminated in $5 \mathrm{~min} . ; 100 \%$ in

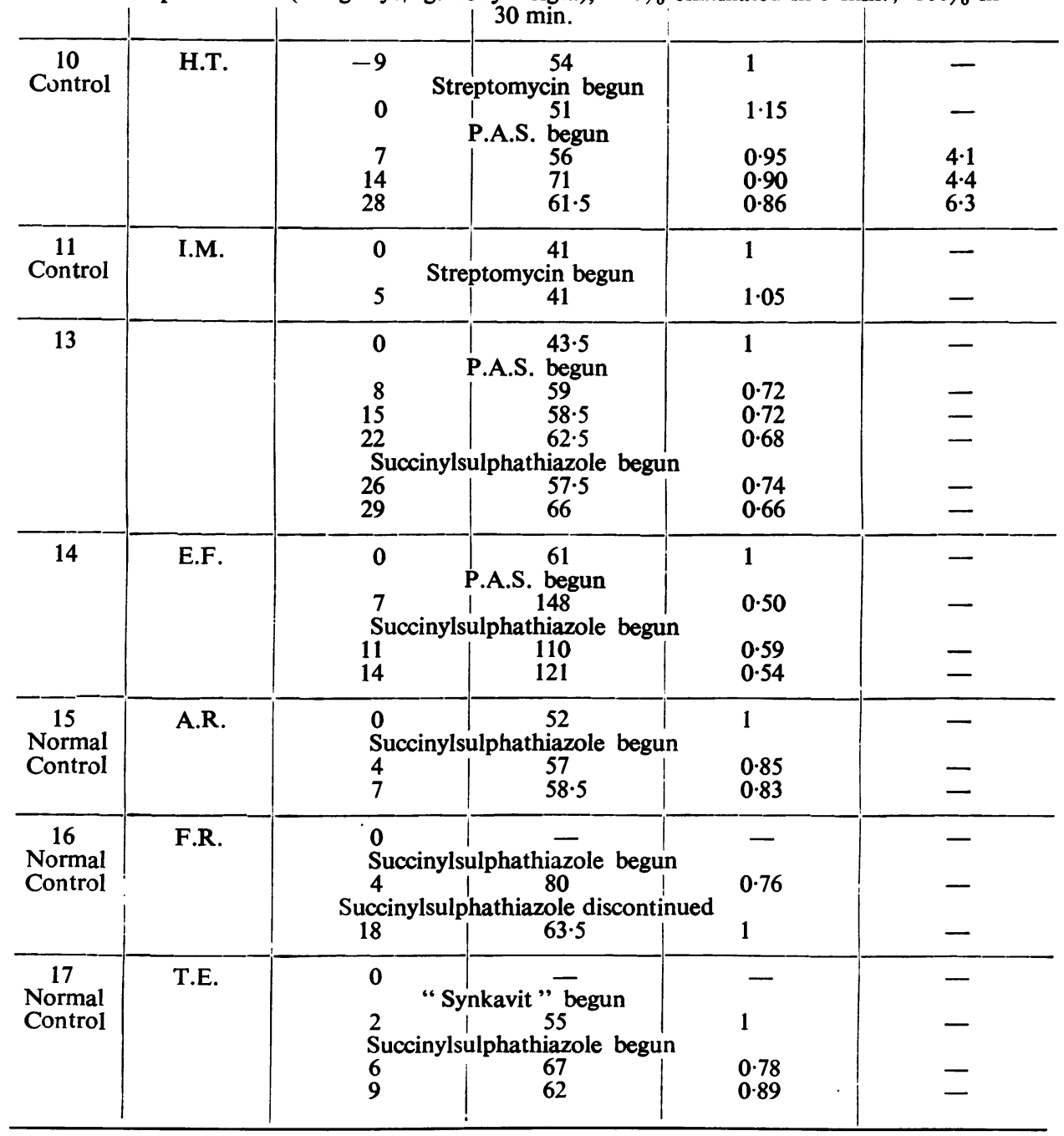


Plasma Prothrombin Time Estimations.-The method of Campbell, Smith, Roberts, and Link (1941) was used, with two modifications. The dried rabbit brain preparation "thromboplastin" (Evans) was used, being stored at $4^{\circ} \mathrm{C}$. over phosphorus pentoxide. Stirring during the final determination of the clotting time consisted of a vertical circular movement of the platinum loop through the mixture of thromboplastin, calcium chloride, and plasma dilution, about once every three seconds, until adherent coagulum was withdrawn. More rapid stirring led to longer and irreproducible results, especially at the higher dilutions of plasma. The usual variation between duplicate determinations was from $\pm 1 \mathrm{sec}$. for $50 \%$ plasma to $\pm 4 \mathrm{sec}$. for $8.33 \%$ plasma. The logarithms of the prothrombin times were plotted against those of the plasma concentrations (Fig. 1). A control log.-log. curve prepared from the patient's own plasma before treatment was used to calculate the "relative clotting index" in subsequent determinations. This obviated the need for arbitrary daily " normal" controls. The " relative clotting index" (Campbell et al., 1941) is the ratio of the concentration of control plasma (in the range of $12.5 \%$ to $8.33 \%)$ to the concentration of test plasma which gives the same clotting time.

Blood P.A.S. Levels.-Total P.A.S. concentrations in oxalated who'e blood were determined by the method of Tárnoky and Brews (1949).

Results.-Specimen curves showing the complete results of several prothrombin determinations on Case 7 (A.L.) are given in Fig. 1. The other charts are specimen curves, showing blood P.A.S. concentrations and prothrombin levels of one patient from each treatment group. These values are recorded as Campbell's " relative clotting indices," and as the prothrombin time of $12.5 \%$ dilutions of plasma in normal saline to conform with the practice usual in this field. All other results are summarized in Table I, which also includes certain relevant laboratory findings.

\section{Discussion}

In determining the prothrombin times of $12.5 \%$ and $8.33 \%$ plasma dilutions slight variations in duplicate results make very little difference in the log.-log. curve, while in $50 \%$ plasma such variation is significant. This, and the fact that an increase in prothrombin time of $50 \%$ plasma by 5 seconds usually involves an increase of about 40 seconds at $8.33 \%$, makes the lower end of the log.-log. curve the more accurate. This may explain the occasional crossing of curves at the $50 \%$ level, although it is possible that an apparent increase in the prothrombin content of full plasma is in fact associated with a fall as observed by the dilution method. Of the two quantities reported the $12.5 \%$ prothrombin time appears to be more sensitive, while the clotting index gives a steadier, and possibly more reliable, guide.

In four of the six cases treated with P.A.S. alone, a rapid fall in the prothrombin level was observed. This, also, was the general picture presented by cases on combined treatment. A slight rise in the prothrombin content following the initial fall in Cases 1 and 4 was accompanied by a drop in their blood P.A.S. levels. This drop may be due to decreased absorption or increased excretion of the drug during the second week, and may explain Bavin's (1949) observation in rabbits that an increase in prothrombin times after five days on P.A.S. fell to an insignificant level after 12 days. This trend, however, was clearly shown in these two cases only. Two cases (Nos. 3 and 6) showed an initial rise in the prothrombin level. This seemed to be due to long initial clotting times which have been reported in tuberculosis by Blom (1942) and by Tanner and Suter (1944). The finding was not followed up in Case 6, and there was a subsequent fall in Case 3. 
Streptomycin partially reverses the antiprothrombin effect of P.A.S., the reversal being most marked at the beginning of streptomycin treatment. Later there is a smaller drop in prothrombin levels. Streptomycin administered parenterally is partly excreted in the bile (Heilman, Heilman, Hinshaw, Nichols, and Herrell, 1945 ; Robinson, 1946), and its antibacterial effect may inhibit the synthesis of dicoumarollike substances by alimentary organisms. The temporary rise in the prothrombin level of Case 10 was probably due to clinical improvement rather than the direct effect of streptomycin, especially as this case had a low initial prothrombin level. The later slow fall in the clotting index might be due to bacterial adaptation to streptomycin or to a delayed vitamin-K deficiency also caused by the antibacterial action of streptomycin. Case 11, a second streptomycin control case, showed no significant effect of streptomycin on the prothrombin time after five days. Thus the further fall in prothrombin levels forecast by Fisher (1949) for cases on combined P.A.S.-streptomycin treatment seems to be overshadowed by the inhibitory effect of streptomycin on dicoumarol synthesis.

The administration of succinylsulphathiazole instead of streptomycin gives much less significant results. There is only a slight return of the prothrombin time towards its initial level, best shown in Case 12, and this is quickly followed by a further fall. In the three normal controls (Cases 15-17), one of whom took "synkavit " before and during the test, succinylsulphathiazole caused a fall in the clotting index. It is known that rats can be made hypoprothrombinaemic by feeding succinylsulphathiazole (Wakim, Krider, and Day, 1943 ; Day, Wakim, Krider, and O'Banion, 1943), and Poth (1945) has referred to an increased incidence of haemorrhage in patients with carcinoma of the colon when treated with this drug. A similar mechanism is reflected in our findings, which are too ill-defined from the point of view of our inquiry, and differ from the clear-cut results of analogous experiments by Jaques and Lepp (1947).

Oral P.A.S. therapy thus has a definite antiprothrombin effect, and our results serve to confirm the findings of other observers. Also P.A.S. seems similar to salicylates in its anticoagulant effect. This latter effect may be explained by Jaques and Lepp's theory rather than Link's. The findings of Barclay (1949), however, still await explanation, especially as they correspond to the results of Link et al. (1943) working with salicylate administered intravenously. These suggest a direct effect due to P.A.S. itself. If salicylates act only through their relation to dicoumarol-like substances, a view Jaques and Lepp do not hold, then, short of a more direct synthesis, a large-scale excretion of parenteral P.A.S. into the alimentary tract would be necessary.

The clinical significance of this anticoagulant effect has been dealt with by Madigan et al. (1950) and Lynch (1950). We may add, however, that P.A.S. has a more marked effect in patients who are in poor condition and especially in cases with liver damage. Such patients generally have longer initial clotting times. The changes due to P.A.S. treatment are reduced by the present practice of giving P.A.S. and streptomycin together. The use of vitamin $\mathrm{K}$ is of course no less justified than in treatment with P.A.S. alone.

\section{Summary}

The effect of oral sodium $p$-aminosalicylate on the prothrombin level was examined in 13 tuberculosis patients. 
Six cases received P.A.S. alone, four were on a combined course of P.A.S. and streptomycin, and three were given succinylsulphathiazole at a point during their course of P.A.S.

P.A.S. caused a definite lowering of prothrombin levels as determined on diluted plasma. This effect was partly reversed by streptomycin. Succinylsulphathiazole gave inconclusive results.

These findings can be explained by the theory of Jaques and Lepp (1947) rather than by that of Link et al. (1943); P.A.S., like salicylates, may be changed to a dicoumarol-like compound by intestinal bacterial action.

We should like to thank Dr. E. N. Allott, Director of the Group Laboratory, Lewisham Hospital, S.E.13, for valuable advice and criticism ; Dr. J. H. F. Wood and Miss V. A. L. Brews for help in the experimental work; and the medical staff of St. Andrew's Hospital, E.3, who made their cases available to us and acted as controls for these observations.

\section{REFERENCES}

Barclay, W. R. (1949). Amer. Rev. Tuberc., 60, 385.

Bavin, E. M. (1949). J. Pharm. Pharmacol., 1, 790.

Blom, K. F. (1942). Svenska Läkartidn., 39, 639.

Campbell, H. A., Smith, W. K., Roberts, W. L., and Link, K. P. (1941). J. biol. Chem., 138, 1.

Clausen, F. W., and Jager, B. V. (1946). J. Lab. clin. Med., 31, 428.

Day, H. G., Wakim, K. G., Krider, M. M., and O'Banion, E. E. (1943). J. Nutrit., 26, 585.

Dibenedetto Dell' Aquila, M., and Lojacono, I. (1946). Boll. soc. ital. Biol. sper., 22, 965.

Drain, D. J., and Seymour, D. E. To be published.

Fisher, J. A. (1949). Lancet, 2, 578.

Heilman, D. H., Heilman, F. R., Hinshaw, H. C., Nichols, D. R., and Herrell, W. E. (1945). Amer. J. med. Sci., 210, 576.

Jaques, L. B., and Lepp, E. (1947). Proc. Soc. exp. Biol., N.Y., 66, 178.

Lester, D. (1944). J. biol. Chem., 154, 305.

Link, K. P., Overman, R. S., Sullivan, W. R., Huebner, C. F., and Scheel, L. D. (1943). Ibid., 147, 463.

Lynch, M. J. G. (1950). J. clin. Path., 3, 114.

Madigan, D. G., Griffiths, L. L., Lynch, M. J. G., Bruce, R. A., Kay, S., and Brownlee, G. (1950). Lancet, 1, 239 .

Meyer, O. O., and Howard, B. (1943). Proc. Soc. exp. Biol., N.Y., 53, 234.

Nagley, M. M. (1949). Practitioner, 163, 459.

Nitshe, G. A., Gerarde, H. W., and Deutsch, H. F. (1947). J. Lab. clin. Med., 32, 410.

O'Connor, J. A. (1948). Postgrad. med. J., 24, 455.

Overman, R. S., Stahmann, M. A., Huebner, C. F., Sullivan, W. R., Spero, L., Doherty, D. G., Ikawa M., Graf, L., Roseman, S., and Link, K. P. (1944). J. biol. Chem., 153, 5.

Owen, G. C., and Bradford, H. A. (1946). Ann. intern. Med., 25, 97.

Poth, E. J. (1945). Surgery, 17, 773.

Robinson, H. J. (1946). Ann. N.Y. Acad. Sci., 48, 119.

Shapiro, S., Redish, M. H., and Campbell, H. A. (1943). Proc. Soc. exp. Biol., N.Y., 53, 251.

Swanson, J. N. (1949). Lancet, 2, 175.

Tanner, E., and Suter, F. (1944). Schweiz. med. Wschr., 74, 552.

Tárnoky, A. L., and Brews, V. A. L. (1949). Biochem. J., 45, 508.

Wakim, K. G., Krider, M. M., and Day, H. G. (1943). Proc. Soc. exp. Biol., N.Y., 54, 164.

Zimmerman, S. P., and Shapiro, S. (1946). Exp. Med. Surg., 4, 110. 